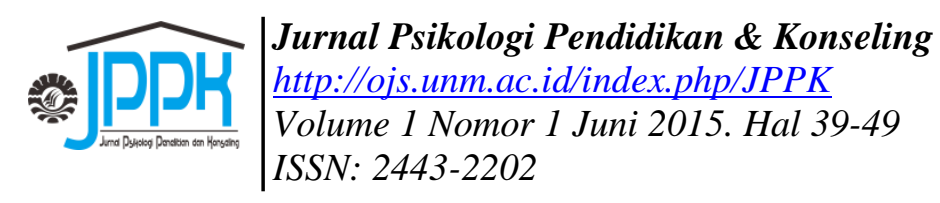

\title{
PENGEMBANGAN MODUL PERENCANAAN KARIER UNTUK SISWA SMP
}

\author{
Musfirah \\ Bimbingan dan Konseling, Universitas Negeri Makassar \\ email: musfirah26@yahoo.co.id
}

\begin{abstract}
For junior high school students, career planning is essential. They need it to help them decide where they will go after graduating. Since curriculum 2013 requires schools to have specified classes at the tenth grade, the students need to have a good career planning before they graduate from the junior high school. This research, thus, aims to develop career planning module for junior high school students which has been theoretically and practically justified and meet the criteria of a small group test and limited group test. There was a preliminary study conducted before developing the module prototype. The module was then validated by four experts and three councelors. Finally, it was tried-out to six students. The developed prototype, therefore, has been verified by the experts validation and students' pretest and posttest.The results of the limited group test (experimental) with a one-group pretest-posttest design to six students have showed the best effect of using the module on career planning guide. In general, the students experienced significant difference in all career planning components: acknowledging their own selves, future school and career, making a career decision, and realizing the plans. For that reason, it is advisable for the counselors to utilize the career planning module as an aid to help students plan on their education.
\end{abstract}

Keywords: Development, module, career planning.

\begin{abstract}
Abstrak: Penelitian ini bertujuan menyusun modul perencanaan karier untuk membantu siswa SMP dalam merencanakan studi lanjut yang teruji secara teoritis maupun praktis, yaitu memenuhi kriteria keberterimaan melalui uji ahli, uji kelompok kecil dan uji kelompok terbatas. Desain penelitian ini menggunakan tiga tahapan yaitu studi pendahuluan, pengembangan dan uji coba. Subjek penelitian yaitu empat orang ahli, tiga orang konselor dan enam orang siswa. hasil uji ahli dan uji kelompok kecil diperoleh hasil bahwa prototype yang dikembangkan telah memenuhi syarat keberterimaan. Hasil uji kelompok terbatas (eksperimen) dengan one-group pretest- posttest design terhadap enam orang siswa, menunjukkan hasil yang nyata bahwa setelah mengikuti kegiatan bimbingan perencanaan karier menggunakan modul rata-rata siswa mengalami peningkatan dalam semua komponen perencanaan karier, yaitu pengetahuan tentang diri sendiri, pengetahuan studi lanjutan, pemilihan rencana karier, pengambilan keputusan karier dan melaksanakan rencana. Disimpulkan terjadi peningkatan setelah mengikuti kegiatan bimbingan perencanaan karier. Hal ini berarti bahwa modul perencanaan karier efektif untuk membantu siswa dalam memilih studi lanjut.
\end{abstract}

Kata kunci: Pengembangan, modul, perencanaan karier. 


\section{PENDAHULUAN}

Bimbingan dan konseling memiliki peran strategis membantu siswa mengarahkan perjalanan hidup, salah satunya melalui perencanaan karier. Kegiatan perencanaan karier siswa dilakukan dalam program layanan perencanaan individual.Perlunya perencanaan pendidikan karier di Sekolah Menengah Pertama didukung oleh teori (seperti Brown \& Trusty, 2005; Niles \& Harris-Bowlsbey, 2005 dalam Trusty, ddk, 2005), ASCA 2003 dan penelitian logitudinal (Adelman, 1999; Trusty, 2004). Hal ini sejalan dengan pendapat Holland (2011) yang menyatakan bahwa perencanaan karier sangat penting bagi siswa dalam menyiapkan karier kelak dengan mempertimbangkan bakat, minat dan kemampuan ekonomi yang dimiliki. Selain itu perencanaan karier mengarahkan siswa fokus pada prestasi dan membantu menyusun strategi dan hal-hal yang diperlukan untuk mencapai tujuan karier (Dahir, 2001).

Hasil penelitian Trusty, ddk, (2005) menemukan bahwa siswa membutuhkan pendidikan perencanaan karier yang efektif untuk siswa Sekolah Menengah Pertama. Pendidikan perencanaan karier yang efektif dimaksudkan untuk membantu siswa dalam pendidikan dan pengembangan karier. Beberapa hasil penelitian juga menjunjukkan bahwa intervensi karier memberikan efek positif pada pengembangan karier siswa secara keseluruhan, seperti hasil penelitian yang dilakukan oleh Schnorr \& Ware, 2001, dkk, Lapan (2007); Lapan, dkk, (2003) dalam Rivera \& Schaefer (2009), Maesaroh (2007), Stringer, dkk, (2001), dan Prediger (2004).

Di sisi lain, hasil penelitian Rivera \& Schaefer (2009: 410) melaporkan bahwa lebih dari $80 \%$ siswa memiliki pemahaman sedikit terkait dengan pekerjaan. Hasil kajian yang dilakukan oleh ILO, 2009 (Pandang, dkk, 2010: 3) di Sulawesi Selatan menunjukkan 92\% dari responden siswa mengaku tidak pernah mendapatkan layanan bimbingan karier dan hanya $7 \%$ yang mengaku pernah mendapatkan layanan tersebut. Dari siswa yang pernah mendapatkan layanan karier tersebut, $82 \%$ menyatakan bahwa layanan bimbingan karier yang diperolehnya sangat membantu mereka dalam menemukan pekerjaan. Dari hasil penelitian itu dapat dilihat bahwa bimbingan karier merupakan hal esensial dalam mengoptimalkan perkembangan vokasional peserta didik.

Saat ini sebagian besar siswa Sekolah Menengah Pertama mengalami kebingungan tentang arah studi lanjut. Lebih parahnya lagi, menurut Integrity Development Flexibility (Harahap, 2014) sebanyak 87\% mahasiswa di Indonesia salah jurusan. Demikian pula dengan alumni Perguruan Tinggi sebagian besar mengalami kebingungan akan kemana dirinya bekerja. Walaupun ijazah sudah ada, mereka merasa ada ketidakcocokan antara ilmu yang dimiliki dengan bidang yang diminati. Hal ini bisa berujung pada pengangguran dan stres. Selain itu menurut Holland (2011) banyak alumni tidak memiliki perencanaan karier sehingga pada saat bekerja mengalami kekecewaan, frustasi dan berkecimpung dalam karier yang menyebabkan ketidakpuasan terhadap kerjanya. Dampak lain jika siswa tidak mempunyai perencanaan yang konsisten dengan tujuan pendidikan mereka, maka akan berakibat negatif pada siswa (Trusty, dkk, 2005). Salah satu penyebab dari fenomena tersebut karena kurangnya informasi tentang karier khususnya perencanaan karier pada jenjang pendidikan menengah sehingga memilih jurusan tanpa ada pertimbangan tanpa melihat bakat dan minat yang dimiliki. Tanpa ada perencanaan karier berarti tidak ada tujuan karier, karenanya tidak ada motivasi untuk mencapai kesuksesan (Cassel, 1998). Selain itu menurut Cheryl (2006) untuk memperoleh pekerjaan yang bagus siswa membutuhkan pendidikan perencanaan karier dan keahlian yang bagus pula. Perencanaan karier di Sekolah Menegah Pertama dilakukan untuk mempersiapkan diri siswa memilih studi lanjut, agar kelak siswa tidak mengalami kebingungan tentang arah karier.

Hasil wawancara dengan konselor pada tanggal 24 Maret 2013 di MTs Bunut Wetan Pakis di kabupaten Malang, diperoleh informasi bahwa konselor mengalami kesulitan memberikan layanan perencanaan karier terhadap siswanya. Salah satu faktor karena kurangnya materi bimbingan karier yang bisa digunakan oleh konselor dalam membantu perencanaan karier siswanya. Hasil need asesssment yang disebarkan pada siswa kelas VIII tanggal 20 September 2013 di MTs Bunut Wetan Pakis diperoleh hasil 61,5\% siswa berada 
pada kategori sangat membutuhkan bimbingan perencanaan karier dan 38,5\% siswa berada pada kategori membutuhkan. Sedangkan hasil need assesment pada siswa kelas VIII tanggal 26 s.d 28 September 2013 di SMP Lab UM hasilnya tidak jauh berbeda yaitu 55,4\% siswa berada pada kategori sangat membutuhkan bimbingan perencanaan karier dan $44,6 \%$ siswa berada pada kategori membutuhkan.

Afifah (2013) menyatakan bahwa dalam kurikulum 2013 mengharuskan pemilihan peminatan dilakukan saat mulai masuk Sekolah Menengah Atas sehingga siswa harus memantapkan rencana karier ketika mereka di Sekolah Menengah Pertama. Namun dari hasil need asessment di atas siswa belum matang dalam perencanaan kariernya dan membutuhkan media yang mempermudah dalam merencanakan karier. Media dipandang sebagai alat komunikasi dalam memberikan materi kepada siswa, sebagaimana diungkapkan Sadiman (2002), bahwa pada dasarnya pembelajaran di kelas merupakan proses komunikasi. Konselor sebagai pemberi informasi memerlukan perantara agar siswa sebagai penerima informasi dapat memahami materi yang disampaikan konselor. Bimbingan perencanaan karier dengan menggunakan modul, bimbingan tidak hanya berfokus pada konselor tetapi siswa dapat melakukan secara mandiri. Penggunaan modul juga tidak bergantung lagi pada media pembelajaran lain atau tidak harus digunakan bersama-sama dengan media yang lain sehingga lebih efesien.

Adapun isi materi modul yang akan dikembangkan diadaptasi dari berbagai ahli perencanaan karier, yang diungkapkan oleh para ahli seperti Brooks (1984), Shertzer \& Stone (1981), Fottler \& Bain (1984), Zunker (1989) dengan urutan yaitu pengetahuan tentang diri sendiri, pengetahuan tentang studi lanjut, pemilihan rencana karier, pengambilan keputusan karier dan melaksanakan rencana. Penggunaan pendapat dari berbagai ahli dengan alasan bahwa perencanaan karier merupakan hal yang kompleks sehingga dalam menyusun materi dibutuhkan pendapat dari banyak ahli.Adapun langkah pengembangan modul dalam penelitian ini mengacu pada sistem instruksional adaptasi dari Dick \& Carey (1978). Struktur penulisan modul mengacu pada struktur penulisan modul oleh Dirjen Pengembangan Mutu (2008). Penyajian bahasa yang digunakan disesuaikan dengan perkembangan karier siswa anak SMP dengan mengacu pada tingkat perkembangan karier yang diungkap oleh Ginzberg (1951), Super (1980), Herr \& Cramer (1984) dan Zunker (1989).

Hasil pengembangan modul perencanaan karier di sekolah dapat digunakan konselor membantu siswa merencanakan kariernya. Selain itu pengembangan modul perencanaan karier dapat digunakan untuk memudahkan siswa merencanakan studi lanjut secara mandiri. Tujuan penelitian dan pengembangan ini adalah mengembangkan modul perencanaan karier untuk membantu siswa Sekolah Menengah Pertama dalam merencanakan studi lanjut yang teruji secara teoritis maupun praktis, yaitu memenuhi kriteria akseptabilitas (ketepatan, kelayakan dan kegunaan) melalui uji ahli, uji kelompok kecil dan uji kelompok terbatas. Tinjauan pustaka terdiri dari bimbingan karier di SMP, program bimbingan karier komprehensif di SMP, media modul, perencanaan karier, model perencanaan karier di SMP, penelitian dan pengembangan.

\section{METODE}

Model penelitian dan pengembangan dalam penelitian ini menggunakan model adaptasi dari prosedur model penelitian dan pengembangan Borg \& Gall (1983). Menurut Sukmadinata (2013), model penelitian ini bisa dimodifikasi menjadi tiga langkah. Adapun modifikasi langkah-langkah tersebut adalah:

1. Tahap I: studi pendahuluan, meliputi asesmen kebutuhan, studi literatur dan menentukan subjek penelitian.

2. Tahap II: pengembangan, meliputi penyusunan draf produk.

3. Tahap III: uji coba, meliputi uji ahli, uji kelompok kecil dan uji lapangan terbatas.

Dalam rangka menghindari kesalahpahaman terhadap istilah-istilah kunci yang digunakan dalam tulisan ini, maka istilahistilah judul: pengembangan modul perencanaan karier untuk siswa SMP perlu diperjelas dengan definisi operasional sebagai berikut:

a. Pengembangan: proses yang berupa langkah-langkah atau tahapan tertentu yang dipergunakan untuk mengembangkan atau menghasilkan suatu produk. Dalam hal penelitian ini produk yang 
dikembangkan adalah modul perencanaan karier untuk siswa Sekolah Menengah Pertama. Rancang bangun penelitian menggunakan Borg \& Gall (1983), sedangkan Pengembangan modul menggunakan desain instruksional dari Dick \& Carey (1978).

b. Modul: sebuah media bimbingan yang berjudul modul perencanaan karier untuk siswa Sekolah Menengah Pertama yang disusun sedemikian rupa sehingga siswa diharapkan dapat menggunakan secara mandiri, praktis dan mudah dipahami untuk mencapai standar kompetensi yang diharapkan dari tiap topik yang disajikan.

c. Perencanaan karier: proses dalam mempersiapkan diri untuk memilih pendidikan lanjutan yang diinginkan siswa dengan menggunakan langkah-langkah: 1) pengetahuan diri sendiri, 2) pengetahuan studi lanjut, 3) pemilihan rencana karier, 4) pengambilan keputusan karier, 5) pelaksanaan rencana sesuai dengan tahapan perkembangan karier siswa Sekolah Menengah Pertama.

d. Sekolah Menengah Pertama (SMP): salah satu jenjang pendidikan dasar pada pendidikan formal yang ditempuh dalam waktu tiga tahun, mulai dari kelas VII sampai kelas IX.

Subjek uji coba prototype terdiri terdiri dari uji ahli, uji coba kelompok kecil dan uji coba kelompok terbatas. Subjek uji ahli produk pengembangan terdiri atas ahli bidang isi produk, ahli perencanaan produk dan atau sasaran pemakai produk (Pedoman Penulisan Karya Ilmiah UM, 2010). Uji kelompok kecil dilakukan pada tiga orang konselor dan Subjek uji lapangan terbatas terdiri dari 6 siswa dari kelas VIII. Instrumen pengumpulan data pada uji ahli dan kelompok kecil berupa angket penilaian. Angket tersebut dikembangkan untuk mengumpulkan penilaian ahli tentang akseptabilitas dari modul perencanaan karier tersebut. Instrumen yang digunakan untuk kelompok terbatas menggunakan angket skala perencanaan karier, pedoman observasi dan wawancara. Teknik analisis data pada uji ahli yang digunakan dalam penilaian modul ini dengan interrater agreement model (Lawshe
(1975) \& Martuza (1977) dalam Gregory, 2000: 99) dan analisis verbal dan uji kelompok kecil menggunakan analisis deksriptif dan analisis verbal. Uji kelompok terbatas dengan menggunakan analisis non parametrik yaitu teknik analisis Wilcoxon Signed-Rank (Santoso, 1999: 301). Teknik Wilcoxon Signed-Rank dilakukan dengan cara menghitung taraf signifikansi perbedaan rerata keterampilan perencanaan karier sebelum dan sesudah di beri perlakuan berupa modul perencanaan karier.

\section{HASIL DAN PEMBAHASAN}

Hasil penelitian pengembangan berupa modul perencanaan karier untuk membantu siswa dalam merencanakan studi lanjut. Modul perencanaan karier untuk siswa berfungsi sebagai media untuk memudahkan siswa dalam merencanakan karier secara mandiri. Modul mencakup tiga bagian pokok yaitu bagian pembuka, bagian inti dan bagian penutup.

Hasil uji coba modul perencanaan karier.Uji ahli dilakukan untuk menguji keberterimaan modul perencanaan karier baik dari aspek ketepatan, kelayakan dan kegunaan. Hasil penilaian yang diperoleh dari uji ahli digunakan untuk merevisi produk sebelum diujikan kepada calon pengguna/konselor. Uji ahli dalam penelitian ini terdiri dari ahli media dan ahli isi. Adapun subjeknya terdiri dari empat orang ahli, yaitu dua orang ahli media dan dua orang ahli isi. Uji ahli rancangan dilakukan melalui dua orang ahli Teknologi Pendidikan, yaitu Bapak Prof. Dr. Punaji Setyosari, M.Pd.,M.Ed., dan Bapak Dr. Anselmus JE Toenlioe, M.Pd,. Sedangkan uji ahli isi dilakukan oleh dua ahli bimbingan dan konseling, yaitu: Ibu Dr. Carolina Ligya Radjah, M.Kes dan Bapak Dr. Triyono, M.Pd., (Dosen Pascasarjana UM).

Hasil penilaian ahli media. Penilaian ahli media dilakukan oleh ahli teknologi pendidikan yang penilaiannya lebih difokuskan pada desain produk pengembangan yang menyangkut perwajahan modul, lay out (tata letak) cover, gambaran pendahuluan dan kemenarikan isi prototype modul perencanaan karier. Data kuantitatif diperoleh dari penilaian ahli media melalui pengisian skala penilaian akseptabilitas produk pengembangan. Data kuantitatif dianalisis secara kuantatif menggunakan interater agreement model dengan menggunakan 
kategori indeks pengklasifikasian validitas yang dikemukakan oleh Guilford (1956). Hasil penilaian ahli media terhadap tampilan secara umum modul perencanaan karier. Berdasarkan penilaian tampilan diperoleh hasil item yang memiliki relevansi rendah dari ahli 1 dan $2(\mathrm{~A})=$ 0 , item yang memiliki relevansi tinggi dari ahli 1 dan relevansi rendah dari ahli $2(\mathrm{~B})=0$, item yang memiliki relevansi rendah dari ahli 1 dan relevansi tinggi dari ahli $2(\mathrm{C})=0$, dan item yang memiliki relevansi tinggi dari ahli 1 dan ahli 2 (D) $=12$. Selanjutnya proses uji ahli media dilakukan dengan kuantikasi hasil uji ahli dengan menggunakan interrater agreement model sebagai berikut:

Pendapat ahli \#1

\begin{tabular}{cc}
$\begin{array}{c}\text { Relevansi rendah } \\
(1-2)\end{array}$ & $\begin{array}{c}\text { Relevansi tinggi } \\
(3-4)\end{array}$ \\
\hline 0 & 0 \\
\hline 0 & 12
\end{tabular}

Gambar 1.1 Hasil penilaian ahli media terhadap tampilan secara umum modul perencanaan karier

Adapun indeks uji ahli dengan menggunakan rumus interrater agreement model:

$$
\frac{\mathrm{D}}{\mathrm{A}+\mathrm{B}+\mathrm{C}+\mathrm{D}}=\frac{12}{0+0+0+12}=\frac{12}{12}=1
$$

Indeks uji ahli yang memiliki nilai 1 berarti memiliki validitas yang sangat tinggi atau dengan kata lain sangat baik. Sehingga disimpulkan bahwa tampilan modul perencanaan karier secara umum tidak perlu banyak perbaikan. Selain menggunakan analisis interrater agreement model, analisis juga dilakukan dengan analisis statistik deskriptif dengan bantuan SPSS 20 nilai rerata dari ahli 1 dan ahli 2 sebesar 3,58 dengan nilai minimum 3 dan nilai maksimum 4. Standar deviasi tidak terlalu besar yaitu 0,51 artinya tampilan modul perencanaan karier secara umum memenuhi kriteria keberterimaan.

Hasil penilaian ahli isi. Penilaian ahli isi dilakukan oleh dua ahli dalam bidang bimbingan dan konseling. Penilaian ahli lebih difokuskan pada konten atau isi dari prototype yang dikembangkan. Penilaian ahli isi menyangkut ketepatan, kelayakan dankegunaan prototype yang dikembangkan.

Penilaian ahli isi terhadap ketepatan prototype modul perencanaan karier. Ketepatan prototype modul perencanaan karier terdiri atas indikator, yaitu: 1) Perumusan dan penjabaran tujuan kompetensi, 2) Analisis konteks. Berdasarkan penilaian ahli isi pada aspek ketepatan diperoleh hasil item yang memiliki relevansi rendah dari ahli 1 dan $2(\mathrm{~A})=0$, item yang memiliki relevansi tinggi dari ahli 1 dan relevansi rendah dari ahli $2(\mathrm{~B})=1$, item yang memiliki relevansi rendah dari ahli 1 dan relevansi tinggi dari ahli $2(\mathrm{C})=0$, dan item yang memiliki relevansi tinggi dari ahli 1 dan ahli $2(\mathrm{D})=12$.

Berdasarkan hasil interrater agreement model diperoleh indeks uji ahli memiliki nilai 0,92 berarti memiliki validitas yang sangat tinggi atau dengan kata lain sangat baik. Sehingga disimpulkan bahwa isi prototype modul perencanaan karier pada aspek ketepatan secara umum sudah tepat. Selain menggunakan analisis interrater agreement model, analisis juga dilakukan dengan analisis statistik deskriptif dengan bantuan SPSS 20 nilai rerata dari ahli 1 sebesar 3,00 dan ahli 2 sebesar 3,15. Nilai minimum pada ahli 1 yaitu 3 dan ahli 2 yaitu 2 dan nilai maksimum pada ahli 1 dan 2 yaitu 4 . Standar deviasi pada ahli 1 yaitu 0,00 dan pada ahli 2 yaitu 0,55 artinya prototype modul perencanaan karier pada aspek ketepatan secara umum sudah tepat.

Penilaian ahli isi terhadap kelayakan prototype modul perencanaan karier. Kelayakan prototype modul perencanaan karier terdiri atas indikator, yaitu: 1) materi modul, 2) kepraktisan prosedur, 3) keefektifan modul. Berdasarkan penilaian ahli isi diperoleh hasil item yang memiliki relevansi rendah dari ahli 1 dan 2 (A) $=0$, item yang memiliki relevansi tinggi dari ahli 1 dan relevansi rendah dari ahli $2(B)=0$, item yang memiliki relevansi rendah dari ahli 1 dan relevansi tinggi dari ahli $2(\mathrm{C})=0$, dan item yang memiliki relevansi tinggi dari ahli 1 dan ahli $2(\mathrm{D})=10$.

Berdasarkan hasil interrater agreement model diperoleh indeks uji ahli yang memiliki 
nilai 1 berarti memiliki validitas yang sangat tinggi atau dengan kata lain sangat baik. Sehingga disimpulkan bahwa isi prototype modul perencanaan karier pada aspek kelayakan secara umum sudah tepat. Selain menggunakan analisis interrater agreement model, analisis juga dilakukan dengan analisis statistik deskriptif dengan bantuan SPSS 20 nilai rerata dari ahli 1 dan ahli 2 sebesar 3,00. Nilai minimum pada ahli 1 dan ahli 2 yaitu 3 dan nilai maksimum pada ahli 1 dan 2 yaitu 3 . Standar deviasi pada ahli 1 dan ahli 2 yaitu 0,00 artinya prototype modul perencanaan karier pada aspek kelayakan secara umum sangat tepat.

Penilaian ahli isi terhadap kegunaan prototype modul perencanaan karier. Kegunaan prototype modul perencanaan karier terdiri atas indikator, yaitu: 1) identifikasi pengguna produk, 2) efek bagi pengguna produk. Berdasarkan penilaian ahli isi diperoleh hasil item yang memiliki relevansi rendah dari ahli 1 dan $2(\mathrm{~A})=0$, item yang memiliki relevansi tinggi dari ahli 1 dan relevansi rendah dari ahli 2 (B) $=0$, item yang memiliki relevansi rendah dari ahli 1 dan relevansi tinggi dari ahli $2(\mathrm{C})=$ 0 , dan item yang memiliki relevansi tinggi dari ahli 1 dan ahli 2 (D) $=10$. Berdasarkan hasilinterrater agreement model diperoleh indeks uji ahli yang memiliki nilai 1 berarti memiliki validitas yang sangat tinggi atau dengan kata lain sangat baik. Sehingga disimpulkan bahwa isi prototype modul perencanaan karier pada aspek kegunaan secara umum sudah tepat.

Selain menggunakan analisis interrater agreement model, analisis juga dilakukan dengan analisis statistik deskriptif dengan bantuan SPSS 20 nilai rerata dari ahli satu sebesar 3,80 dan ahli dua sebesar 3,00. Nilai minimum pada ahli satu yaitu 3 dan ahli dua yaitu 3 dan nilai maksimum pada ahli satu yaitu 4 dan ahli dua yaitu 3 . Standar deviasi tidak terlalu besar, pada ahli satu yaitu 0,42 dan pada ahli dua yaitu 0,00 artinya prototype modul perencanaan karier pada aspek kegunaan secara umum sudah tepat.

Hasil penilaian uji konselor. Uji kelompok kecil (konselor) dilakukan untuk menguji keberterimaan modul perencanaan karier baik dari aspek ketepatan, kelayakan dan kegunaan. Hasil penilaian yang diperoleh dari konselor digunakan untuk merevisi protoype sebelum diujikan kepada kelompok terbatas atau siswa. Adapun subjeknya terdiri dari tiga orang konselor di SMP Lab UM yaitu Bapak Fardika Sihiyantoro, S.Pd, Ibu Ayun Ulfatul Jannah, S.Pd dan Bapak M. Arif Rahman, S.Pd.

Penilaian konselor terhadap ketepatan prototype modul perencanaan karier. Ketepatan prototype modul perencanaan karier terdiri atas indikator, yaitu: 1) Perumusan dan penjabaran tujuan kompetensi, 2) Analisis konteks. Hasil penilaian konselor tersebut kemudian dianalisis dengan menggunakan statistik deskriptif dengan menggunakan SPSS 20. Adapun hasil dari konselor satu yaitu nilai rerata sebesar 3,23, nilai minimum 2 dan nilai maksimum 4 dengan total nilai 42. Standar deviasi tidak terlalu besar, pada konselor satu yaitu 0,59. Hasil dari konselor dua yaitu nilai rerata sebesar 3,00, nilai minimum 3 dan nilai maksimum 3 dengan total nilai 39. Standar deviasi yaitu 0,00 . Sedangkan hasil dari konselor tiga yaitu nilai rerata sebesar 3,23 , nilai minimum 3 dan nilai maksimum 4 dengan total nilai 42. Standar deviasi tidak terlalu besar, pada konselor tiga yaitu 0,43 . Hal ini berarti prototype modul perencanaan karier pada aspek kegunaan secara umum sudah memenuhi kriteria ketepatan.

Penilaian konselor terhadap kelayakan prototype modul perencanaan karier. Kelayakan prototype modul perencanaan karier terdiri atas indikator, yaitu: 1) materi modul, 2) kepraktisan prosedur, 3) keefektifan modul. Hasil penilaian konselor tersebut kemudian dianalisis dengan menggunakan statistik deskriptif dengan menggunakan SPSS 20. Adapun hasilnya dari konselor satu yaitu nilai rerata sebesar 4,00, nilai minimum 4 dan nilai maksimum 4 dengan total nilai 40. Standar deviasi pada konselor satu yaitu 0,00 . Hasil dari konselor dua yaitu nilai rerata sebesar 2,80 , nilai minimum 2 dan nilai maksimum 3 dengan total nilai 28. Standar deviasi tidak terlalu besar, yaitu 0,42 . Sedangkan hasil dari konselor tiga yaitu nilai rerata sebesar 3,50, nilai minimum 3 dan nilai maksimum 4 dengan total nilai 35. Standar deviasi tidak terlalu besar, pada konselor tiga yaitu 0,52. Hal ini berarti prototype modul perencanaan karier pada aspek kelayakan secara umum sudah memenuhi kriteria kelayakan.

Penilaian konselor terhadap kegunaan prototype modul perencanaan karier. Kegunaan prototype modul perencanaan karier terdiri atas indikator, yaitu: 1) identifikasi pengguna produk, 2) efek bagi pengguna produk. Hasil 
penilaian konselor tersebut kemudian dianalisis dengan statistik deskriptif menggunakan SPSS 20. Adapun hasilnya dari konselor satu yaitu nilai rerata sebesar 3,40 , nilai minimum 3 dan nilai maksimum 4 dengan total nilai 34 . Standar deviasi pada konselor satu yaitu 0,51 . Hasil dari konselor dua yaitu nilai rerata sebesar 3,30, nilai minimum 3 dan nilai maksimum 4 dengan total nilai 33. Standar deviasi tidak terlalu besar, yaitu 0,48 . Sedangkan hasil dari konselor tiga yaitu nilai rerata sebesar 3,40 , nilai minimum 3 dan nilai maksimum 4 dengan total nilai 34 . Standar deviasi tidak terlalu besar, pada konselor tiga yaitu 0,51. Hal ini berarti prototype modul perencanaan karier pada aspek kegunaan secara umum sudah memenuhi kriteria kegunaan.

Hasil uji lapangan terbatas (siswa). Uji lapangan terbatas dilakukan dengan menggunakan tes awal (pretest) dan tes akhir (posttest) yang diukur dengan menggunakan skala perencanaan karier. Adapun subjek yang digunakan sebanyak enam orang, yaitu YS, DV, $\mathrm{NY}, \mathrm{CH}, \mathrm{AG}, \mathrm{AF}$. Pemilihan subjek lapangan didasarkan pada hasil pretest dan memberikan peluang yang sama antara jumlah laki-laki dan perempuan untuk menghindari bias gender. Uji lapangan terbatas dimaksudkan untuk mengetahui keefektifan dari penggunaan prototype modul perencanaan karier dalam membantu siswa merencanakan studi lanjut.

Hasil pretest dan posttest dianalisis secara kelompok dengan menggunakan uji statistik Wilcoxon. Analisis perkelompok dilakukan untuk mengetahui perbedaan sebelum dan sesudah pelaksanaan bimbingan perencanaan karier. Bimbingan perencanaan karier diberikan kepada enam orang siswa. Adapun hasil pretest dan posttest adalah sebagai berikut:

Tabel. 1.1 Hasil Pretest dan Posttest dalam Mengikuti Kegiatan Bimbingan Perencanaan Karier

\begin{tabular}{ccccccc}
\hline No & Nama & Pretest & Kategori & Posttest & Kategori & Selisih \\
\hline 1 & CH & 48 & Rendah & 92 & Tinggi & 47 \\
\hline 2 & NY & 45 & Rendah & 92 & Tinggi & 46 \\
\hline 3 & AG & 48 & Rendah & 93 & Tinggi & 45 \\
\hline 4 & AF & 49 & Rendah & 89 & Tinggi & 40 \\
\hline 5 & DV & 49 & Rendah & 91 & Tinggi & 42 \\
\hline 6 & YS & 49 & Rendah & 97 & Sangat tinggi & 48 \\
\hline & & & & 2,201 didapat & angka kumulatif sebesar $0,986$.
\end{tabular}

Berdasarkan hasil pretest dan posttest pada tabel 1.1 terdapat perbedaan skor baik sebelum maupun sesudah. Adanya perbedaan ini menunjukkan bahwa setelah bimbingan perencanaan karier dengan menggunakan prototype modul perencanaan terjadi peningkatan. Untuk mengetahui besarnya signifikansi peningkatan nilai skor rata-rata pretest dan posttest diperlukan uji statistik Wilcoxon. Berdasarkan hasil uji statistik Wilcoxondiperoleh harga $\mathrm{Z}$ sebesar $-2,201$ dengan Asymp. Sig. (2-tailed) 0,028 yaitu <a 0,05 , jadi $\mathrm{H}_{0}$ ditolak, maka disimpulkan terjadi peningkatan setelah mengikuti kegiatan bimbingan perencanaan karier. Hal ini berarti bahwa modul perencanaan karier efektif untuk membantu siswa dalam memilih studi lanjut. Adapun logika probabilitas yaitu dari z hitung didapat nilai 2,201 (tanda - tidak relevan karena hanya menunjukan arah). Dari tabel z angka
Hal ini berarti bahwa probabilitas adalah 10,986 atau 0,014 . Oleh karena uji dua sisi maka probabilitas (asymp.Sig) adalah $2 \times 0,014$ atau 0,028 .

Selain itu dilakukan wawancara dengan siswa tentang pengalaman mereka menggunakan prototype modul perencanaan karier.

Berdasarkan hasil wawancara, respon siswa pada pengalaman dalam menggunakan modul perencanaan karier umumnya menjawab bahwa mereka senang dalam menggunakan modul karena mampu merencanakan karier.

Pembahasan hasil produk. Pembahasan memuat kajian teoritis dan empiris terhadap komponen-komponen yang terdapat dalam modul. Kajian ini memiliki tujuan untuk mendiskusikan temuan yang diperoleh selama proses pengembangan produk dengan teori yang ada sehingga produk ini memiliki kekuatan 
ilmiah. Pembahasan difokuskan pada temuan yang miliki hubungan dengan hasil uji ahli, hasil uji konselor dan hasil uji kelompok terbatas. Berdasarkan hasil penilaian ahli isi dan media serta penilaian dari konselor bahwa pengembangan modul perencanaan karier dipandang telah memenuhi kriteria keberterimaan. Hal ini dapat dilihat dari hasil penilaian yang tinggi dari para ahli, hasil uji konselor dan hasil uji kelompok terbatas dengan menggunakan desain one-group pretest-postest design. Pembahasan uji ahli meliputi dua aspek keberterimaan yaitu keberterimaan ahli media dan keberterimaan ahli isi. Berdasarkan hasil uji ahli menunjukkan hasil bahwa modul perencanaan karier yang dikembangkan sangat berguna untuk siswa SMP. Namun demikian ada beberapa catatan penting baik dari ahli media maupun dari ahli konten sebagai bagah untuk melakukan revisi terhadap prototype modul perencanaan karier. Berdasarkan hasil uji kelompok kecil kepada konselor secara umum disimpulkan bahwa prototype modul perencanan karier telah memenuhi kriteria keberterimaan. Konselor menilai bahwa prototype modul perencanaan karier sangat membantu konselor dalam memberikan bimbingan perencanaan karier. Selama ini konselor dalam memberikan bimbingan perencanaan karier hanya sebatas pada kegiatan klasikal melalui metode ekpositori. Konselor menyadari bahwa dengan adanya modul proses bimbingan lebih efektif dan memberikan kemudahan konselor dalam mengarahkan karier siswa. Selain itu adanya kurikulum 2013 yang mengharuskan peminatan di mulai pada saat awal masuk SMA (Afifah, 2013) membuat konselor harusnya mempunyai bahan bimbingan dalam membantu siswa merencanakan karier. Uji kelompok terbatas menggunakan one group pretest-postest design. Adapun subjeknya sebanyak enam orang yang dipilih dari hasil pretest.

Data dari hasil pretest dan posttest menunjukkan bahwa terdapat peningkatan skor antara pretest maupun posttest pada masingmasing siswa setelah diberikan bimbingan perencanaan karier menggunakan modul. Peningkatan skor ini menunjukkan bahwa bimbingan perencanaan karier menggunakan modul terjadi peningkatan dalam aspek (1) pengetahuan tentang diri sendiri, (2) pengetahuan studi lanjut, (3) pemilihan studi lanjut, (4) pengambilan keputusan karier, (5) pelaksanan rencana karier.

Selanjutnya berdasarkan hasil uji statistik menggunakan Wilcoxon menunjukkan bahwa prototype modul perencanaan karier yang dikembangkan terbukti efektif meningkatkan rencana studi lanjut siswa SMP. Hal ini disebabkan karena modul menggunakan bahasa yang mudah dipahami, operasional, menarik, materi yang padat dan memperhatikan perbedaan individual siswa serta adanya umpan balik yang lebih sering dari pada bimbingan secara konvensional. Hal ini sejalan dengan pendapat Gagne, dkk (1988: 315) pembelajaran modul menyediakan umpan balik dan pemeriksaan perkembangan lebih sering daripada pembelajaran secara konvensional. Selain itu menurut Wijaya (1992) menyatakan bahwa dalam pengajaran modul sangat dimungkinkan: 1) adanya peningkatan motivasi belajar secara maksimal, 2) adanya peningkatan kreaktivitas guru dalam menyiapkan alat dan bahan yang diperlukan dan pelayanan individual yang lebih mantap, 3) dapat mewujudkan prinsip maju berkelanjutan secara tidak terbatas, 4) dapat mewujudkan belajar yang lebih berkonsentrasi (Sukiman, 2012: 133)

Berkaitan dengan penggunaan modul sebagai bahan bimbingan pada siswa SMP didasarkan pada teori perkembangan kognitif (Piaget,1954) bahwa anak usia 11 tahun keatas berada pada tahap operasional formal (formal operation). Pada tahap operasional formal seorang anak sudah mampu mengatasi masalah abstrak secara logis, menjadi lebih ilmiah dalam berpikir serta sudah mampu mengembangkan kepedulian tentang isu-isu sosial dan identitas (Papalia, Olds, \& Fieldman, 2009; Santrock, 2005; Woolfolk, 2009). Adanya teori tersebut maka sistem belajar mandiri dengan menggunakan modul dianggap cocok untuk siswa SMP. Peningkatan kemampuan siswa dalam merencanakan karier juga didukung oleh beberapa faktor penunjang seperti self-efficacy siswa, tujuan karier, dukungan sosial, kepribadian siswa, serta situasi dan kondisi saat pelaksaan bimbingan perencanaan karier dilaksanakan. Hal ini sesuai dengan hasil penelitian Rogers, dkk, (2008) dan Rogers \& Creed (2011).

\section{SIMPULAN DAN SARAN}


Berdasarkan pembahasan hasil penelitian yang telah dilakukan, maka disimpulkan:

1. Penelitian yang telah dilakukan menghasilkan produk berupa modul perencanaan karier untuk siswa SMP, yang mencakup tiga bagian pokok yaitu bagian pembuka, bagian inti dan bagian penutup. Bagian pembuka memuat tentang 1) judul, 2) kata pengantar, 3) daftar isi,4) kata pengantar, 5) tujuan modul, 6) petunjuk penggunaan modul, 7) tes awal. Bagian inti terdiri modul dari: 1) tinjauan umum materi, 2) hubungan dengan materiyang lain 3) uraian materi, 4) kesimpulan, 5) tugas latihan, 6) evaluasi diri.Selain itu untuk mempermudah siswa dalam memahami setiap modul maka diakhir setiap modul disediakan lembar ringkasan panduan. Bagian penutup terdiri dari glosarium dan daftar pustaka.

2. Hasil uji ahli isi dan media, secara umum terhadap prototype modul perencanaan karier yang dikembangkan telah memenuhi kriteria keberterimaan. Hal ini dapat dilihat dari hasil penilaian ahli isi dan ahli media dengan analisis interrater agreement model berada pada kategori indeks uji validitas sangat tinggi. Dalam artian prototype yang dikembangkan dinilai sangat akseptabel. Begitu pula dengan hasil penilaian ahli media yang diolah dengan uji statistik dekriptif menunjukkan rerata atau mean 3,58 dengan standar deviasi 0,515 artinya prototype yang dikembangkan telah akseptabel. Penilaian ahli isi yang diolah dengan uji statistik dekriptif menunjukkan rerata atau mean 3,15 dengan standar deviasi 0,39 artinya prototype yang dikembangkan telah akseptabel.

3. Hasil uji kelompok kecil (konselor) secara umum terhadap prototype modul perencanaan karier yang dikembangkan telah memenuhi kriteria keberterimaan. Hal ini dapat dilihat dari hasil uji statistik deskriptif menunjukkan rerata atau mean 3,30 dengan standar deviasi 0,483 artinya prototype yang dikembangkan telah akseptabel.

4. Hasil uji kelompok terbatas (eksperimen) terhadap prototype modul perencanaan karier yang dikembangkan, menunjukkan hasil yang nyata bahwa setelah mengikuti kegiatan bimbingan perencanaan karier menggunakan modul rata-rata siswa mengalami peningkatan dalam semua komponen perencanaan karier.

Perubahan kurikulum KTSP menjadi kurikulum 2013, maka disarankan bagi konselor untuk memantapkan karier siswa sejak di SMP

Prototype modul perencanaan karier dapat membantu siswa dalam merencanakan studi lanjut maka disarankan kepada konselor sekolah untuk menerapkan di sekolah. Pengujian efektivitas modul perencanaan karier dalam membantu siswa merencanakan karier masih terbatas pada enam subjek saja. Disarankan bagi peneliti selanjutnya melakukan penelitian untuk skala yang lebih luas dengan terlebih dahulu melakukan asesmen kebutuhan pada tempat yang akan dipergunakan untuk penelitian. Perlu dilakukan penelitian lebih lanjut tentang penilaian keefektivan bimbingan modul perencaan karier setelah beberapa saat dilakukan bimbingan modul perencaan karier (misalnya pada akhir semester).

\section{DAFTAR RUJUKAN}

Adelman, C. 1999. Answers in The Tool Box: Academic Intensity, Attendance Patterns, and Bachelor's Degree Attainment. Washington, DC: U.S. Department of Education. (online) (http://www2.ed.gov/pubs/Toolbox/toolb ox.html ), diakses 27 Januari 2014.

Afifah, R. 12 Februari 2013. Guru BK Dilatih agar Siswa Tak Salah Peminatan. Harian Kompas.

American School Counselor Association. 2013. The ASCA National Model: A Framework for School Counseling. Alexandria. VA: Author.

Borg, W.R \& Gall, M. D. 1983. Educational Research An Introduction. 1983. New York: Longman.

Brooks, L. 1984. Career Planning Programs in Work Place. Dalam Brown, Duane., Brooks, L \& Associates. 1984. Career Choice and Development. San Fransisco: Jossey-Bass Publisher.Pp 388-405.

Brown, D and Associates. 2002. Career Choice and Development $-4^{\text {th }}$ Ed. San Fransisco: Jossey-Bass Publisher. 
Brown, D. 2007. Career Information, Career Counseling, and Career Information. United States of America: Pearson Education.

Brown, D \& Brooks, L. 1990. Career Counseling Techniques. United States of America: Allyn and Bacon.

Cassel, R. N. 1998. High School Success and School Accountability Begin with Tentative Job-Career Plans For Each Student. Journal of Education. Vol 119 (2) 319 (Online), (http://www. ProQuest Professional Education.com).

Cheryl, D. 2006. A New Tool For Career Decision-Making.Journal of Techniques. Vol 81(3) (Online), (http://www. ProQuest Professional Education.com).

Crites, J.O. 1981. Career Counseling Models, Method and Materials. United States of America: McGraw-Hill Book Company.

Dick, W \& Carey L. 1978. The Systematic Design of Instruction. USA: Scott, Foresman and Company.

Dirjen Peningkatan Mutu. 2008. Penulisan Modul. Jakarta: Departemen Pendidikan Nasional.

Dahir, C. A. 2001. Career Planning in Midle School. Journal The Education Digest. Vol 67 (4) 65-67 (Online), (http://www. ProQuest Professional Education.com).

Fottler; M.D. \& Bain, T. 1984. Realism of Occupational Choice Among High School Seniors: Implications for Quality of Work Life, Occupational Behaviour,5: 4, 237-251. 55.

Gagne, R. M., Brings, L.J \& Wager, W.W. 1988. Principle of Instructional Design $3^{\text {th }} E d$. New York: Holt, Rinehart and Winston, Inc.

Gregory, R.J. 2000. Psychological Testing: History, Principle, and Applications: $3^{\text {rd }}$ ed. USA: Allyn \& Bacon.

Guilford, J. P. 1956. Fundamental Statistics in Psychology and Education. New York: Mc Graw-Hill Book Co. Inc.

Harahap, R F. 25 Februari 2014. Duh, 87\% Mahasiswa Indonesia Salah Jurusan. Okezone.com (online). (http://kampus.okezone.com/read/2014/ 02/24/373/945961/duh-87-mahasiswaindonesia-salah-jurusan), diakses 27 Februari 2014.
Herr, E. L \& Cramer, S.H. 1984.Career Guidance and Counseling Through The Life Span. United State of America: Little Brown \& Company.

Holland, J.M. 2011. Career Development Planning: Getting Students on The Right Track. (Online). (www. acteonline.org), di akses 26 Januari 2014.

Maesaroh. Hubungan Konsep Diri dan Informasi Karier dengan Perencanaan Karier Siswa SMA: Studi Kearah Pengembangan Pengembangan Program Perencanaan Karier di SMA PGRI Bandung. (Online). (http: //digilib.upi.edu/pasca/available), di akses 12 Februari 2013.

Pandang, A., Sunarty, K \& Malik, M, A . 2006. Pengembangan Model Bimbingan Karier untuk Meningkatkan Kecerdasan Wirausaha Siswa SMA. Laporan Penelitian Hasil Strategis Nasional. Dipa Universitas Negeri Makassar.

Papalia, D.E., Olds, S.W \& Feldman, R.D. 2008. Human Development. Terjemahan Brian Marswendy. 2009. Jakarta: Salemba Humanika.

Prediger, D.J. 2004. Career Planning Validity of Self-Estimates and Test Estimates of Work-Relevant Abilities. Journal The Career Development Quarterly. Vol 52 (3) 202 (Online), (http://www. ProQuest Professional Education.com).

Rivera, L.M. \& Schaefer, M. B. 2009. The Career Institute: A Collaborative Career Development Program for Traditionally Underserved Secondary (6-12) School Students. Journal of Career Development.Vol 35 (4). (Online), (http://www.sagepublications.com). 
Rogers, M. E., Creed, P. A., Glendon, A.I. 2008.The Role Of Personality in Adolescent Career Planning and Exploration: A social cognitive perspective. Journal of Vocational Behavior.Vol $73 . \quad$ (Online). (http://www.sciencedirect.com ).

Rogers, M.E \& Creed, P. A. 2011.A Longitudinal Examination Of Adolescent Career Planning and Exploration Using A Social Cognitive Career Theory Framework. Journal of Adolescence, Vol 34.(Online). (http://www.sciencedirect.com ).

Sadiman, A. 2002. Media Pendidikan: Pengertian, Pengembangan, dan Pemanfaatannya. Jakarta:Rajawali Press.

Santoso, S. 1999. SPSS Mengolah Data Statistik Secara Profesional. Jakarta: PT Elex Media Komputindo.

Santrock, J.W. 1995. Life Span Development. Terjemahan Juda Damanik \& Achmad Husairi. 2002. Jakarta: Erlangga.

Shertzer, B \& Stone, S.H. 1981. Fundamental of Guindance. $4^{\text {th }}$ Edition. Boston: Houghton Mifflin company.

Stringer, K., Kerpelman, J., \& Skorikov, V. 2011. Career Preparation: A Longitudinal, Process-Oriented Examination. Journal of Vocational Behavior. Journal of Vocational Behavior. $\quad$ Vol 79. (Online).(http://www.sciencedirect.com) Sukiman. 2012. Pengembangan Media Pembelajaran. Yogyakarta: Pedagogia.

Sukmadinata, N.S. 2013. Metode Penelitian Pendidikan. Bandung: PT. Remaja Rosdakarya.

Trusty, J. 2004. Effects of Students' MiddleSchool and High-School Experiences on Completion of the Bachelor's Degree. (Research Monograph No. 1) Amherst, MA: Center for School Counseling Outcome Research. (http://www.umass.edu/schoolcounse ling/index.htm), diakses 27 Januari 2014.

Trusty, J., Niles, S, G., \& Carney, J,V. 2005. Educational-Career Planning and Middle School Counselor. Journal Professional School Counseling. Vol
9 (2) (Online), (http://www. ProQuest Professional Education.com.

Woolfolk, A. 2008. Educational Psychology Active Learning Edition. Terjemahan Helly Prajitno Soetjipto \& Sri Mulyantini Soetjipto. 2008. Yogyakarta: Pustaka Pelajar.

Zunker, V.G. 1989. Career Counseling Applied Concepts of Life Planning. California: Brooks/Cole Publishing Company. 